\title{
Plasma LH and FSH responses and ovarian activity in prepubertal heifers treated with repeated injections of low doses of GnRH for $72 \mathrm{~h}$
}

\author{
B. J. McLeod, A. R. Peters, W. Haresign and G. E. Lamming \\ A.F.R.C. Research Group on Hormones and Farm Animal Reproduction, University of Nottingham \\ School of Agriculture, Sutton Bonington, Loughborough, Leics LE12 5RD, U.K.
}

\begin{abstract}
Summary. Twelve 5-month-old Hereford $\times$ Friesian heifers were injected i.v. with $2 \cdot 0$ $\mu \mathrm{g} \mathrm{GnRH}$ at 2-h intervals for $72 \mathrm{~h}$. Blood samples were collected at 15 -min intervals from $24 \mathrm{~h}$ before the start until $8 \mathrm{~h}$ after the end of the GnRH treatment period. Over the 24-h pretreatment period, mean $\mathrm{LH}$ concentrations ranged from 0.4 to $2.2 \mathrm{ng} / \mathrm{ml}$ and FSH concentrations from $14 \cdot 1$ to $157.4 \mathrm{ng} / \mathrm{ml}$; $\mathrm{LH}$ episodes (2-6 episodes $/ 24 \mathrm{~h}$ ) were evident in all animals. Each injection of $\mathrm{GnRH}$ resulted in a distinct episode-like response in $\mathrm{LH}$, but not FSH. Mean LH, but not FSH, concentrations were significantly increased by GnRH treatment. The GnRH-induced LH episodes were of greater magnitude than naturally-occurring episodes (mean maximum concentration $6.7 \pm 0.5$ and $4.9 \pm 0.6 \mathrm{ng} / \mathrm{ml}$ respectively). Preovulatory LH surges occurred between 17.0 and $58.8 \mathrm{~h}$ after the start of treatment in $9 / 12$ heifers, with a coincident FSH surge in 8 of these animals. This was not followed by normal luteal function. There were no apparent correlations between pretreatment hormone concentrations, and either the pituitary response to $\mathrm{GnRH}$ or the occurrence of preovulatory gonadotrophin release.
\end{abstract}

\section{Introduction}

In the naturally-cyclic ewe and cow, the final stages of maturation of preovulatory follicles are associated with a period of high-frequency episodic LH release (Baird, 1978; Rahe, Owens, Fleeger, Newton \& Harms, 1980). In contrast, LH episodes occur infrequently during periods of ovarian inactivity, for example, seasonal or post-partum anoestrus (Yuthasastrakosol, Palmer \& Howland, 1977; Lamming, Wathes \& Peters, 1981). Similarly, LH episodes occur infrequently during the prepubertal period in both species, and puberty occurs only after the frequency characteristic of the follicular phase of the oestrous cycle is attained (Ryan \& Foster, 1980; Schams, Schallenberger, Gombe \& Karg, 1981; Day et al., 1984; McLeod, Haresign, Peters \& Lamming, 1984). In contrast, FSH concentrations in the prepubertal heifer, with the exception of the absence of preovulatory surges, do not differ markedly from those recorded during the oestrous cycle of the adult animal (Akbar, Reichert, Dunn, Kaltenbach \& Niswender, 1974).

Repeated administration of LH or GnRH to increase LH episode frequency will restore normal ovarian cycles in the post-partum acyclic cow (Riley, Peters \& Lamming, 1981; Walters et al., 1982) and the seasonally anoestrous ewe (McLeod, Haresign \& Lamming, 1982a, b; McNeilly, O'Connell \& Baird, 1982). This treatment stimulates follicle growth and oestradiol production, and eventually results in preovulatory gonadotrophin surges and ovulation. Injections of low doses of GnRH have also been reported to induce episode-like release of $\mathrm{LH}$ in prepubertal heifers as young as 4 months of age (McLeod et al., 1984), but in that trial the duration of GnRH treatment was much less than that necessary to induce ovulation in mature cows (Riley et al., 1981). The current experiment was therefore undertaken to determine whether an extended period of treatment with low doses of 
GnRH would eventually result in preovulatory surge secretion of gonadotrophins and ovarian activity in young prepubertal heifers.

\section{Materials and Methods}

\section{Animals and management}

Twelve Hereford $\times$ Friesian heifers, aged approximately 5 months (mean \pm s.e.m. bodyweight $171 \pm 5 \cdot 3 \mathrm{~kg}$ ), were housed indoors under conditions of natural daylength and temperature and fed concentrates and hay twice daily. They were run as a single group except during the period of intensive blood sampling, when all animals were restrained individually.

\section{Treatment and blood sampling}

After the insertion of a jugular vein catheter $48 \mathrm{~h}$ earlier, all animals were given i.v. injections of $2.0 \mu \mathrm{g}$ GnRH (Lutal: Fabwerke Hoechst A.G., Frankfurt, West Germany) in $2 \mathrm{ml}$ sterile saline $(0.9 \% \mathrm{NaCl}, \mathrm{w} / \mathrm{v})$ at 2 -h intervals for $72 \mathrm{~h}$. Blood samples $(2 \mathrm{ml})$ for gonadotrophin determination were collected via the jugular vein catheter at 15-min intervals from $24 \mathrm{~h}$ before the start, until $8 \mathrm{~h}$ after the end of GnRH treatment (a total period of $104 \mathrm{~h}$ ). Throughout the treatment period the blood samples were taken immediately before administration of GnRH. Blood samples (10 ml) for progesterone determination were collected by jugular venepuncture every 2 nd day from 2 days before the start until 24 days after the end of GnRH treatment.

\section{Hormone analyses}

$L H$. Plasma LH concentrations were measured by the specific double-antibody radioimmunoassay method of Webb, Lamming, Haynes, Hafs \& Manns (1977). The limit of sensitivity of the assay within this study was $0.4 \mathrm{ng}$ NIH-LH-B 9 equiv. $/ \mathrm{ml}$ plasma, and the inter- and intra-assay coefficients of variation were $11.9 \%(n=12)$ and $6.3 \%(n=50)$ respectively.

$F S H$. Blood samples were assayed for FSH by the specific heterologous radioimmunoassay of Webb, Lamming, Haynes \& Foxcroft (1980). Within this study the limit of sensitivity of the assay was $9.7 \mathrm{ng} \mathrm{NIH-FSH-Bl} \mathrm{equiv./ml} \mathrm{plasma,} \mathrm{and} \mathrm{the} \mathrm{inter-} \mathrm{and} \mathrm{intra-assay} \mathrm{coefficients} \mathrm{of} \mathrm{variation}$ were $12.8 \%(n=12)$ and $8 \cdot 2 \%(n=50)$ respectively.

Progesterone. Plasma progesterone concentrations were determined by the specific radioimmunoassay method previously described (Webb et al., 1977). The limit of sensitivity within this study was $0.2 \mathrm{ng} / \mathrm{ml}$, the inter- and intra-assay coefficients of variation were $12.3 \%(n=8)$ and $6.4 \%(n=50)$ respectively, and the mean extraction efficiency was $74.8 \%$.

\section{Analysis of data}

An LH episode was defined by the criteria previously described by McLeod et al. (1982a), i.e. (i) an increase of at least $50 \%$ above the preceding baseline value, (ii) at least 2 points between the peak value and the succeeding trough or baseline, and (iii) a rate of decline in concentrations after the peak no greater than that allowed by the known half-life of the hormone. The definition used to characterize a preovulatory surge was (i) that there was a sustained $(>5 \mathrm{~h}$ ) elevation in LH concentrations above $4.0 \mathrm{ng} / \mathrm{ml}$ and (ii) that the peak concentration attained during this time exceeded $10 \mathrm{ng} / \mathrm{ml}$. The onset of this peak was defined as that time when the concentration first reached $4.0 \mathrm{ng} / \mathrm{ml}$.

Normal luteal function was defined as a sustained elevation in plasma progesterone concentrations of $>1.0 \mathrm{ng} / \mathrm{ml}$ for at least 10 days, starting within 5 days of the preovulatory LH surge. 
Mean LH and FSH concentrations, and mean LH episode frequencies, were determined for individual animals over the pretreatment and treatment periods. Differences between pretreatment and treatment values, and between responsive and non-responsive animals, were assessed by one-way analysis of variance, Students $t$ test or $\chi^{2}$ analysis. In addition, changes in the LH response to GnRH injections were analysed by linear regression and FSH concentrations were subjected to power spectral analysis, a time series technique designed to identify recurring periodicities in the data (McLeod \& Craigon, 1985).

All results are expressed as mean \pm s.e.m.

\section{Results}

\section{Gonadotrophin concentrations}

Individual profiles of plasma LH and FSH concentrations for 3 heifers are shown in Text-fig. 1. These animals are selected to demonstrate both the patterns of gonadotrophin secretion typical of these prepubertal heifers over the pretreatment period and the range of responses observed to GnRH treatment.

During the 24-h pretreatment period, mean plasma LH concentrations in individual heifers ranged from 0.4 to $2.5 \mathrm{ng} / \mathrm{ml}$ (Table 1). LH episodes were evident in all animals and occurred with a frequency of 2-6 episodes/24 h. Mean basal LH concentrations (excluding episodic secretion) ranged from 0.4 to $2.3 \mathrm{ng} / \mathrm{ml}$ plasma.

In 10/12 heifers, each GnRH injection induced an episode-like release of $\mathbf{L H}$, at least until the onset of a preovulatory LH surge (see Text-fig. 1). In the remaining 2 animals (Heifers 1 and 3), LH episodes occurred in response to most, but not all, injections of GnRH. The mean maximum concentration of GnRH-induced $\mathrm{LH}$ episodes $(6.7 \pm 0.5 \mathrm{ng} / \mathrm{ml})$ was significantly greater $(P<0.01)$ than that of naturally-occurring episodes $(4.9 \pm 0.6 \mathrm{ng} / \mathrm{ml})$ recorded during the pretreatment period. Furthermore, overall mean LH concentrations over the period extending from the start of GnRH treatment until the onset of the preovulatory LH surge, were significantly greater $(P<0.001)$ than mean pretreatment concentrations $(3.0 \pm 0.3 \mathrm{ng} / \mathrm{ml}$ and $1.4 \pm 0.2 \mathrm{ng} / \mathrm{ml}$ respectively).

Preovulatory LH surges were recorded in $9 / 12$ heifers and occurred at a mean time of $41 \cdot 2 \pm 4 \cdot 3$

Table 1. Liveweights and characteristics of plasma LH and FSH concentrations over the 24-h pretreatment period in 5-month-old prepubertal heifers

\begin{tabular}{|c|c|c|c|c|c|}
\hline Heifer & $\begin{array}{l}\text { Liveweight } \\
\text { (kg) }\end{array}$ & $\begin{array}{c}\text { Mean } \\
\text { LH conc. } \\
\text { (ng/ml) }\end{array}$ & $\begin{array}{l}\text { Basal* }^{*} \\
\text { LH conc. } \\
\text { (ng/ml) }\end{array}$ & $\begin{array}{c}\text { No. } \\
\text { of LH } \\
\text { episodes } / 24 \mathrm{~h}\end{array}$ & $\begin{array}{c}\text { Mean } \\
\text { FSH conc. } \\
\text { (ng/ml) }\end{array}$ \\
\hline 1 & 158 & $2 \cdot 2$ & 1.9 & 4 & 29.8 \\
\hline 2 & 162 & 1.4 & 1.0 & 5 & 38.4 \\
\hline 3 & 176 & 2.5 & $2 \cdot 3$ & 4 & 63.0 \\
\hline 4 & 148 & 1.6 & 1.3 & 6 & $18 \cdot 3$ \\
\hline 5 & 156 & 0.4 & 0.4 & 2 & 62.5 \\
\hline 6 & 174 & 0.8 & 0.5 & 5 & 19.7 \\
\hline 7 & 188 & 0.7 & 0.7 & 2 & 28.0 \\
\hline 8 & 174 & 0.9 & 0.4 & 4 & 134.6 \\
\hline 9 & 200 & 0.9 & 0.6 & 5 & 49.5 \\
\hline 10 & 164 & $2 \cdot 0$ & $1 \cdot 2$ & 6 & $14 \cdot 1$ \\
\hline 11 & 156 & $1 \cdot 3$ & 0.7 & 4 & 157.4 \\
\hline 12 & 206 & $2 \cdot 2$ & $1 \cdot 8$ & 3 & $153 \cdot 7$ \\
\hline Mean & $171 \pm 5 \cdot 3$ & $1.4 \pm 0.2$ & $1 \cdot 1 \pm 0 \cdot 2$ & $4 \cdot 2 \pm 0 \cdot 4$ & $64 \cdot 1 \pm 15 \cdot 5$ \\
\hline
\end{tabular}

* Excluding endogenous LH episodes. 

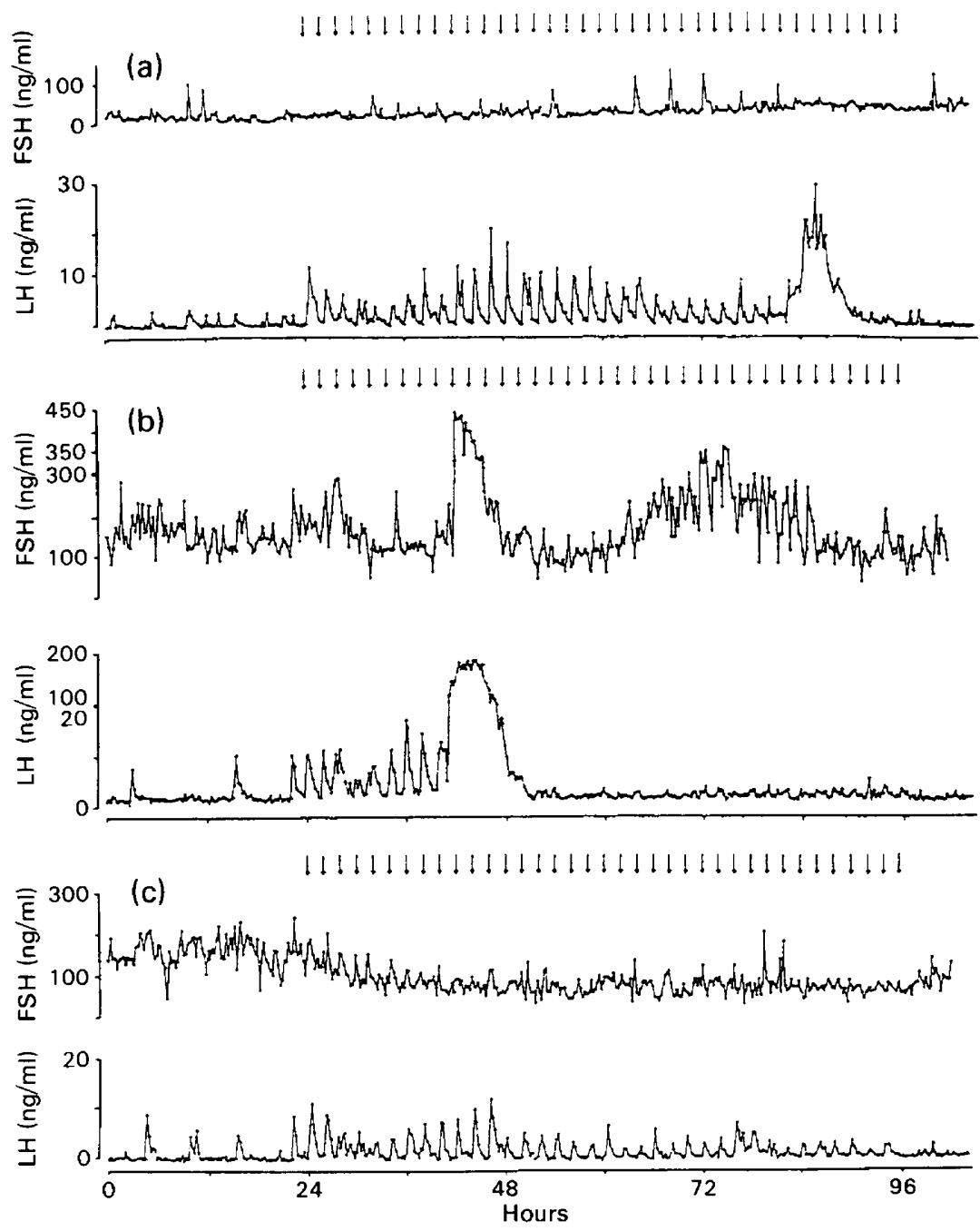

Text-fig. 1. Plasma LH and FSH concentrations in 3 prepubertal heifers before, and in response to i.v. injections of $2.0 \mu \mathrm{g} \mathrm{GnRH}$ given at 2-h intervals for $72 \mathrm{~h}$. These profiles show (a) Heifer 4 in which the preovulatory LH surge occurred late in the treatment period and was not associated with an FSH surge, (b) Heifer 12 in which there was a coincident surge of LH and FSH early in the treatment period and (c) Heifer 8 in which there was no preovulatory LH/FSH surge. The times of GnRH injections are indicated by the arrows. Blood samples were collected at 15 -min intervals.

$\mathrm{h}$ (range 17.0 to $58.8 \mathrm{~h}$ ) after the start of GnRH treatment. Although the time of onset varied widely between animals, the heifers could be classified into 4 groups on the basis of the timing of the preovulatory LH surge (see Table 2), namely, those in which the preovulatory surge occurred early $(17.0 \mathrm{~h}$, Heifer 12$)$, intermediate $(36.4 \pm 1.7 \mathrm{~h}$, Heifers $2,5,7 \& 9)$ or late $(52.1 \pm 3.0 \mathrm{~h}$, Heifers, 1 , $4,6 \& 10$ ) in the GnRH treatment period, and those in which a surge was not recorded (Heifers 3,8 \& 11). Maximum LH surge concentrations attained ranged from 12.4 to $193.7 \mathrm{ng} / \mathrm{ml}$ (see Table 2), and the duration of the preovulatory surge from $5 \cdot 3$ to $10 \cdot 5 \mathrm{~h}$.

Pretreatment mean FSH concentrations ranged from 14.1 to $157.4 \mathrm{ng} / \mathrm{ml}$ plasma in individual animals with a mean value of $64.1 \pm 15.5 \mathrm{ng} / \mathrm{ml}$ (Table 1). Although FSH levels remained 
Table 2. Mean plasma concentrations of $\mathrm{LH}$ and FSH, and characteristics of preovulatory gonadotrophin surges in 5-month-old heifers treated with i.v. injections of $2.0 \mu \mathrm{g} \mathrm{GnRH}$ at $2-\mathrm{h}$ intervals for $72 \mathrm{~h}$

\begin{tabular}{|c|c|c|c|c|c|}
\hline \multirow[b]{2}{*}{ Heifer } & \multicolumn{2}{|c|}{$\begin{array}{l}\text { Mean plasma } \\
\text { concentrations* }\end{array}$} & \multicolumn{3}{|c|}{ Preovulatory gonadotrophin surges } \\
\hline & $\begin{array}{c}\mathrm{LH} \\
(\mathrm{ng} / \mathrm{ml})\end{array}$ & $\begin{array}{l}\text { FSH } \\
(\mathrm{ng} / \mathrm{ml})\end{array}$ & $\begin{array}{l}\text { Time of } \\
\text { onset }+(h)\end{array}$ & $\begin{array}{c}\text { Maximum LH } \\
\text { conc. }(\mathrm{ng} / \mathrm{ml})\end{array}$ & $\begin{array}{l}\text { Maximum FSH } \\
\text { conc. (ng/ml) }\end{array}$ \\
\hline 12 & $5 \cdot 7$ & 144.2 & 17.0 & 193.7 & 439.9 \\
\hline 7 & $2 \cdot 9$ & $31 \cdot 3$ & $32 \cdot 3$ & $27 \cdot 0$ & 61.8 \\
\hline 2 & $3 \cdot 3$ & 36.9 & $36 \cdot 0$ & 48.1 & 97.8 \\
\hline 5 & 1.4 & 56.0 & 36.5 & 18.0 & $135 \cdot 2$ \\
\hline 9 & $2 \cdot 4$ & $29 \cdot 3$ & 40.8 & 39.6 & 115.6 \\
\hline 4 & $3 \cdot 3$ & 15.9 & 47.0 & $12 \cdot 4$ & 58.6 \\
\hline 10 & $3 \cdot 4$ & $11 \cdot 4$ & 47.0 & 58.8 & 68.4 \\
\hline 1 & $3 \cdot 3$ & 36.0 & 55.7 & 39.7 & 70.2 \\
\hline 6 & $3 \cdot 0$ & $20 \cdot 5$ & 58.8 & 27.4 & - \\
\hline 3 & $2 \cdot 7$ & 37.5 & - & - & - \\
\hline 8 & 1.9 & 97.4 & - & - & - \\
\hline 11 & $2 \cdot 2$ & $73 \cdot 7$ & - & - & - \\
\hline Mean & $3 \cdot 0 \pm 0 \cdot 3$ & $49 \cdot 2 \pm 11 \cdot 2$ & $41 \cdot 2 \pm 4 \cdot 3$ & $51 \cdot 5 \pm 18 \cdot 4$ & $130 \cdot 9 \pm 45 \cdot 2$ \\
\hline
\end{tabular}

\footnotetext{
* Mean concentrations are based on samples collected from the start of GnRH treatment until the onset of the preovulatory surge in those animals exhibiting surges, and throughout the treatment period in those not producing a surge.

† Time from the start of GnRH treatment (see text).
}

relatively constant in some heifers throughout the $24-\mathrm{h}$ pretreatment period, in others they fell or rose markedly before the start of GnRH treatment (see Text-fig. 1). The mean FSH concentrations (excluding preovulatory surges) of individual animals throughout the period of GnRH treatment ranged from 11.4 to $144.2 \mathrm{ng} / \mathrm{ml}$, giving an overall mean value of $49.2 \pm 11.2 \mathrm{ng} / \mathrm{ml}$ (see Table 2). These were not significantly different from pretreatment levels. No consistent changes in plasma FSH concentrations were apparent in response to GnRH administration, and few GnRH-induced episodes could be identified by visual appraisal of hormone profiles (see Text-fig. 1). Time series analysis detected a number of recurring periodicities in FSH secretion of apparently random frequency over the pretreatment period. However, during the period of $2 \mathrm{~h} \mathrm{GnRH}$ injections, a 2-h cycle in FSH secretion was interposed in $8 / 12$ animals. In contrast, such a pattern was apparent in only one heifer over the pretreatment period.

Preovulatory FSH surges (mean maximum concentration of $130.9 \pm 45.2 \mathrm{ng} / \mathrm{ml}$ ) occurred in $8 / 9$ heifers in which preovulatory LH surges were recorded. A further elevation in FSH concentrations was observed $24 \mathrm{~h}$ later in those animals in which the sampling period was long enough (see Text-fig. 1b).

There were no significant differences in mean liveweight, pretreatment gonadotrophin concentrations, or in the immediate response to repeated injections of $\mathrm{GnRH}$, between those animals that subsequently produced preovulatory gonadotrophin surges and those that did not.

\section{Progesterone concentrations}

Plasma progesterone concentrations were low (mean \pm s.e.m., $0 \cdot 3 \pm 0 \cdot 1 \mathrm{ng} / \mathrm{ml}$ ) in all heifers before GnRH treatment. In 3 animals (Heifers 2, 6 \& 9) progesterone concentrations rose above $1 \cdot 0$ $\mathrm{ng} / \mathrm{ml} 4$ or 5 days after the preovulatory gonadotrophin surge but returned to basal levels 1 or 2 days later, indicative of transient luteal activity. In all other animals progesterone concentrations remained low $(0 \cdot 3 \pm 0 \cdot 1 \mathrm{ng} / \mathrm{ml})$ throughout the sampling period. 


\section{Discussion}

A characteristic of tonic LH secretion in the prepubertal heifer is the low frequency with which LH episodes occur. The pattern of LH secretion, recorded over the $24 \mathrm{~h}$ preceding the GnRH treatment period, was similar to that reported previously for heifers of this age (McLeod et al., 1984). The LH episode frequency (mean rate $4 \cdot 2 \pm 0 \cdot 4$ episodes $/ 24 \mathrm{~h}$ ) was similar to that reported earlier for the acyclic post-partum cow (Riley et al., 1981), but the mean baseline concentrations of LH (excluding episodes) were markedly higher. Similarly, FSH concentrations (mean $64.1 \pm 15.5 \mathrm{ng} / \mathrm{ml}$, range 14.1 to $157.4 \mathrm{ng} / \mathrm{ml}$ ) in these heifers over the pretreatment period, were in agreement with earlier reports for the prepubertal animal (Gonzalez-Padilla, Wiltbank \& Niswender, 1975a; Schams et al., 1981; McLeod et al., 1984).

In this study, a frequency of episodic LH secretion comparable to that occurring during the follicular phase of the oestrous cycle was imposed on 5-month-old heifers by repeated injections of $2 \mu \mathrm{g}$ GnRH. Previous studies (McLeod et al., 1984) had indicated that this was the minimum dose level required to ensure a consistent $\mathrm{LH}$ response to all $\mathrm{GnRH}$ injections in heifers of similar ages and weights. Furthermore, work in the seasonally anoestrous ewe has shown that an 8-fold difference in the dose of GnRH has little effect on the size of the induced LH episodes, or on the efficacy of repeated injections of $\mathrm{GnRH}$ to induce ovulation (McLeod et al., 1982b). In some animals in this study, the maximum LH concentration recorded decreased with successive injections of GnRH (see Text-fig. 1c). Indeed, when all animals were included in the analysis, there was a significant negative correlation $(P<0.01, r=-0.51)$ between maximum $\mathrm{LH}$ concentration in response to each GnRH injection, and time from the start of treatment. While this could be interpreted as evidence of pituitary refractoriness, in some animals there were alternating periods of increasing and decreasing sensitivity to GnRH injections (see Text-fig. 1a), which is likely to be the result of steroid modulation of pituitary responsiveness rather than a progressive desensitization. Such fluctuations in pituitary sensitivity to $\mathrm{GnRH}$ have also been reported to occur throughout the treatment period when seasonally anoestrous ewes are subjected to continuous infusion of low doses of GnRH (McLeod et al., 1983).

In contrast to the consistent LH episode response to GnRH injections, GnRH-induced FSH episodes were not obvious by simple inspection of hormone profiles. However, time series analysis, which is capable of detecting regularly recurring cycles in secretion even when baseline levels are fluctuating markedly, detected a 2-h cycle in FSH secretion in 8/12 heifers over the GnRH treatment period. Nevertheless, the presence of an FSH response to GnRH injections did not appear to determine whether a preovulatory gonadotrophin surge would occur. The $\mathbf{4}$ heifers in which time series analysis failed to detect a 2-h pattern of FSH secretion subsequently produced preovulatory LH/FSH surges, while, conversely, a 2-h cycle in FSH concentrations was detected in the 3 animals in which preovulatory surges were not observed.

Staigmiller, Short \& Bellows (1979) and Schillo, Dierschke \& Hauser (1983) reported that the positive feedback mechanism in heifers becomes functional between 3 and 5 months of age. The occurrence of preovulatory gonadotrophin surges in only a proportion (9/12) of 5-month-old heifers treated with GnRH may therefore reflect differences between individual animals in the maturity of this component of hypothalamo-pituitary activity. These workers also reported that when LH release was induced in 5-month-old heifers by a standard dose of oestradiol, the magnitude of the LH surge varied greatly, indicative of considerable between-animal variation in the sensitivity of the hypothalamo-pituitary axis. Similarly, in the current study the magnitude of the preovulatory LH surges varied widely (maximum concentration $12.4-193.7 \mathrm{ng} / \mathrm{ml}$ ). There was however, no apparent relationship between the amplitude of the episodic response to $\mathrm{GnRH}$ and the timing, magnitude or incidence of preovulatory surges. Such variation, therefore, may merely reflect differences in the ovarian response, and thus in plasma oestradiol concentrations, between animals. Indeed, it is not clear from these results whether the preovulatory LH/FSH surges were produced as a result of the direct effects of GnRH injections, or of the positive feedback effects of 
oestradiol from follicles induced to grow by the GnRH-induced increase in LH episode frequency. However, data from seasonally anoestrous ewes subjected to a similar treatment regimen clearly indicate that the preovulatory surge was due to the positive feedback effects of high levels of oestradiol (McLeod \& Haresign, 1984). Further work is therefore required to establish the basis of variation in responses observed.

The failure of some animals to produce a preovulatory surge may have been attributable to 'stress' effects incurred by the intensive handling and blood loss (about $20 \%$ of total volume over 5 days). It has been demonstrated that hyperadrenal states interfere with GnRH-induced preovulatory LH release (Li \& Wagner, 1983).

In all 7 animals in which the blood sampling period continued for long enough, a 2 nd rise of FSH was recorded about $24 \mathrm{~h}$ after the preovulatory LH/FSH surge, producing a pattern of release similar to that seen in the naturally-cyclic adult animal (Dobson, 1978). This 2nd FSH rise may be due to the escape of the hypothalamo-pituitary axis from the feedback effects of follicular secretions at the time of ovulation.

The absence of normal luteal function in this trial does not necessarily preclude the occurrence of ovulation in these animals, as a proportion of $\mathrm{GnRH}$-induced ovulations in similarly-treated seasonally anoestrous ewes produce abnormal corpora lutea, unless the animals are pretreated with progesterone (McLeod et al., 1982b). In addition, Gonzalez-Padilla, Wiltbank \& Niswender (1975b) demonstrated that progesterone pretreatment was required to produce normal corpora lutea in heifers in which ovulation was induced by injection of oestradiol. However, it has yet to be determined whether the GnRH treatment used in the present study induces ovulation in the prepubertal heifer, and, if so, whether progesterone pretreatment influences the functional competence of the resultant corpora lutea.

We thank the A.F.R.C. and Hoechst Pharmaceuticals for financial support; Hoechst Pharmaceuticals for supplies of GnRH; and NIH, Bethesda, U.S.A. for standard LH and FSH.

\section{References}

Akbar, A.M., Reichert, L.E., Dunn, T.G., Kaltenbach, C.C. \& Niswender, G.D. (1974) Serum levels of follicle-stimulating-hormone during the bovine estrous cycle. J. Anim. Sci. 39, 360-365.

Baird, D.T. (1978) Pulsatile secretion of LH and ovarian estradiol during the follicular phase of the sheep estrous cycle. Biol. Reprod. 18, 359-364.

Day, M.L., Imakawa, K., Garcia-Winder, M., Zalesky, D.D., Schanbacher, B.D., Kittock, R.J. \& Kinder, J.E. (1984) Endocrine mechanisms of puberty in heifers: Estradiol negative feedback regulation of luteinizing hormone secretion. Biol. Reprod. 31, 332-341.

Dobson, H. (1978) Plasma gonadotrophins and oestradiol during oestrus in the cow. J. Reprod. Fert. 52, 51-53.

Gonzalez-Padilla, E., Wiltbank, J.N. \& Niswender, G.D. (1975a) Puberty in beef heifers. I. The interrelationship between pituitary, hypothalamic and ovarian hormones. J. Anim. Sci. 40, 1091-1104.

Gonzalez-Padilla, E., Niswender, G.D. \& Wiltbank, J.N. (1975b) Puberty in beef heifers. II. The effect of injections of progesterone and estradiol- $17 \beta$ on serum LH, FSH and ovarian activity. J. Anim. Sci. 40, 11051109.

Lamming, G.E., Wathes, D.C. \& Peters, A.R. (1981) Endocrine patterns of the post-partum cow. $J$. Reprod. Fert., Suppl. 30, 155-170.

Li, P.S. \& Wagner, W.C. (1983) In vivo and in vitro studies on the effects of adrenocorticotrophic hormone or cortisol on the pituitary response to gonadotrophin releasing hormone. Biol. Reprod. 29, 25-37.

McLeod, B.J. \& Craigon, J. (1985) Time series analysis of plasma concentrations of $\mathrm{LH}$ and $\mathrm{FSH}$ as a method of assessing episodic secretion. J. Reprod. Fert. (in press).

McLeod, B.J. \& Haresign, W. (1984) Induction of fertile oestrus in seasonally anoestrous ewes with low doses of GnRH. Anim. Reprod. Sci. 7, 413-420.

McLeod, B.J., Haresign, W. \& Lamming, G.E. (1982a) The induction of ovulation and luteal function in seasonally anoestrous ewes treated with small-dose multiple injections of Gn-RH. J. Reprod. Fert. 65, 215-221.

McLeod, B.J., Haresign, W. \& Lamming, G.E. (1982b) Response of seasonally anoestrous ewes to small-dose multiple injections of Gn-RH with and without progesterone pretreatment. J. Reprod. Fert. 65, 223 230.

McLeod, B.J., Haresign, W. \& Lamming, G.E. (1983) Induction of ovulation in seasonally anoestrous ewes by continuous infusion of low doses of Gn-RH. $J$. Reprod. Fert. 68, 489-495.

McLeod, B.J., Haresign, W., Peters, A.R. \& Lamming, G.E. (1984) Plasma LH and FSH concentrations in 
prepubertal beef heifers before and in response to repeated injections of low doses of Gn-RH.J. Reprod. Fert. 70, 137-144.

McNeilly, A.S., O'Connell, M. \& Baird, D.T. (1982) Induction of ovulation and normal luteal function by pulsed injections of luteinizing hormone in anestrous ewes. Endocrinology 110, 1292-1299.

Rahe, C.H., Owens, R.E., Fleeger, J.L., Newton, H.J. \& Harms, P.G. (1980) Pattern of plasma luteinizing hormone in the cyclic cow: dependence upon the period of the cycle. Endocrinology 107, 498-503.

Riley, G.M., Peters, A.R. \& Lamming, G.E. (1981) Induction of pulsatile $\mathrm{LH}$ release, $\mathrm{FSH}$ release and ovulation in post-partum beef cows by repeated small doses of GnRH. J. Reprod. Fert. 63, 559-565.

Ryan, K.D. \& Foster, D.L. (1980) Neuroendocrine mechanisms involved in onset of puberty in the female: concepts derived from the lamb. Fedn Proc. Fedn Am. Socs exp. Biol. 39, 2372-2377.

Schams, D., Schallenberger, E., Gombe, S. \& Karg, H. (1981) Endocrine patterns associated with puberty in male and female cattle. J. Reprod. Fert., Suppl. 30, 103-110.

Schillo, K.K., Dierschke, D.J. \& Hauser, E.R. (1983) Estrogen-induced release of luteinizing hormone in prepubertal and post-pubertal heifers. Theriogenology 19, 727-738.

Staigmiller, R.B., Short, R.E. \& Bellows, R.A. (1979) Induction of $\mathrm{LH}$ surges with $17 \beta$-estradiol in prepubertal beef heifers: an age dependent response. Theriogenology 11, 453-459.

Walters, D.L., Short, R.E., Convey, E.M., Staigmiller, R.B., Dunn, T.G. \& Kaltenbach, C.C. (1982) Pituitary and ovarian function in post-partum beef cows. III. Induction of estrus ovulation and luteal function with intermittent small-dose injections of Gn-RH. Biol. Reprod. 26, 655-662.

Webb, R., Lamming, G.E., Haynes, N.B., Hafs, H.D. \& Manns, J.G. (1977) Response of cyclic and postpartum suckled cows to injections of synthetic LHRH. J. Reprod. Fert. 50, 203-210.

Webb, R., Lamming, G.E., Haynes, N.B. \& Foxcroft, G.R. (1980) Plasma progesterone and gonadotrophin concentrations and ovarian activity in post-partum dairy cows. J. Reprod. Fert. 59, 133-143.

Yuthasastrakosol, P., Palmer, W.M. \& Howland, B.E. (1977) Release of LH in anoestrous and cyclic ewes. $J$. Reprod. Fert. 50, 319-321.

Received 19 October 1984 